\title{
KBRN Tehdit ve Tehlikelerden Kaynaklı Zararlar Nedeniyle İdarenin Risk İlkesine Dayalı Sorumluluğu
}

\author{
Utku ÜTÜK ${ }^{1}$
}

Öz

KBRN (Kimyasal, Biyolojik, Radyolojik, Nükleer) maddelerin kaza ile veya kasıtlı olarak çevreye yayılması önemli can ve mal kayıplarına yol açmakta ayrıca uzun bir zaman dilimi boyunca olumsuz etkiler doğurmaktadır. KBRN tehdit ve tehlikelerinin önlenmesi ve oluşabilecek zararların azaltılması konusunda ise idareye önemli rol düşmekte, bu bakımdan idarenin KBRN maddeler kaynaklı zararlar bakımından mali sorumluluğu önemli bir sorun alanı haline gelmektedir. İdari işlem ve eylemler nedeniyle idarenin sorumluluğu kusurlu ve kusursuz sorumluluk olmak üzere iki şekilde ortaya çıkmaktadır. Kusursuz sorumluluk genellikle risk ilkesine dayalı sorumluluk ve fedakârlığın denkleştirilmesi ayrımı doğrultusunda ele alınmaktadır. Çalışmada KBRN tehdit ve tehlikeler nedeniyle oluşan zararlarda idarenin risk ilkesine dayalı sorumluluğuna odaklanılmıştır. Öncelikle genel olarak Türk Hukukunda idarenin risk ilkesi altında sorumluluğu açıklanmış, ardından idarenin KBRN tehdit ve tehlikeler kaynaklı zararlar bakımından sorumluluğu risk ilkesi bağlamında çözümlenmiştir.

Anahtar Kelimeler: Kusursuz Sorumluluk, Risk İlkesi, Sosyal Risk İlkesi, KBRN Tehdit ve Tehlikeler.

\section{Administrative Responsibility Regarding the Loss Stemming From CBRN Threats And Hazards Under Risk Principle}

\begin{abstract}
Abstarct
The dispersion of CBRN (Chemical, Biological, Radiological, Nuclear) materials in environment accidentally or intentionally causes mortality and a great loss of property besides leading to long lasting negative effects. Administrative authorities may play critical role in preventing CBRN threats and hazards and reducing damages arising from CBRN. In this respect pecuniary liability of administration regarding the loss generating from CBRN materials becomes an important issue. Administrative responsibility with regard to administrative transactions and actions emerge as faulty and strict liability. Strict liability is generally dealed under risk principle and balancing of sacrifices principle distinction. This paper focuses on administrative responsibility arising from CBRN threats and hazards under risk principle. In the first instance administrative responsibility under risk principle in Turkish Law is explained. As for the following part administrative responsibility regarding the loss stemming from CBRN threats and hazards is analyzed in accordance with the risk principle.
\end{abstract}

Keywords: Administrative Responsibility, Strict Liability, Risk Principle, Social Risk Principle, CBRN Threats and Hazards.

\footnotetext{
${ }^{1}$ Savunma Sanayii Müsteşarlığı, Savunma Sanayii Uzmanı (Müdür), uutuk@ssm.gov.tr, 05319784920

*ilgili yazar / Corresponding author: okayn@itu.edu.tr

Gönderim Tarihi: 05.06.2018

Kabul Tarihi: 28.06.2018
} 


\section{Giriş}

KBRN tehdit ve tehlikeler KBRN maddelerinden elde edilen silahların kasten terör ve sabotaj eylemlerinde kullanılması veya KBRN maddelerin sanayii ve sağlık alanlarında veya laboratuvarlarda ve bilimsel araştırmalarda kullanımı sırasında kaza ile çevreye dağılması ile oluşmaktadır. Bu tehdit ve tehlikelere bağlı olarak ortaya çıkan KBRN olaylar ise "kimyasal, biyolojik, radyoaktif ve nükleer maddelerin kasten veya kazaen yayılmasıyla oluşan, insan ve çevre için zararlı ve tehlikeli durumlara yol açan olay" olarak tanımlanmaktadır (AFAD, 2014: 23; 100). KBRN olaylar nedeniyle toplumun tamamı veya belirli bir kesimi bakımından fiziksel, ekonomik ve sosyal kayıpların ortaya çıkması, yaşamın olağan akışının ve insan etkinliklerinin aksaması veya kesintiye uğraması ve olayın etkilediği alandaki insanların kendi kapasiteleri ile meydana gelen olumsuz durumun üstesinden gelememesi halinde ${ }^{2}$ KBRN afetler oluşmaktadır.

KBRN olaylar tarihsel süreçte çevre, iklim, insan yaşamı, toplumsal düzen üzerinde önemli etkiler doğurmuştur. Günümüzde ise teknolojik gelişmeler, hızı sanayileşme, silahlanmada artış, silahlara terörist gruplar gibi devlet dışı aktörlerin erişmesi, uluslararası alanda giderek artan gerginlikler ve siyasi gerilimlere bağlı olarak KBRN maddelerin kazaen veya kasten çevreye yayılma olasılığı artmaktadır (URL-1). KBRN tehdit ve tehlikelerin niteliği ve boyutu göz önünde bulundurulduğunda idareye bu tehdit ve tehlikelerinin önlenmesi ve oluşabilecek zararların azaltılması konusunda önemli rol düştüğü açıktır. Bu doğrultuda gerçekleşen KBRN tehdit ve tehlikelere bağlı olarak meydana gelen zararlar bakımından idarenin mali sorumluluğu idare hukuku bağlamında incelenmesi gereken önemli bir sorun alanıdır.

Hukukta "sorumluluk" kavramını genel olarak bir kişi tarafından diğerine verilen zararın giderilmesi yükümlülüğü şeklinde açıklamak mümkündür. Verilen zararın nedeni ve niteliği, gerek sorumluluğa bağlı olarak doğacak yükümlülüğü gerekse tabi olunacak hukuki rejimi farklılaştırmaktadır (Atay, 2010:33). Hukukta; siyasi sorumluluk, cezai sorumluluk ve mali sorumluluk şeklinde farklı sorumluluk türleri bulunmaktadır. Hukuki sorumluluk olarak da adlandırılan mali sorumluluk; medeni sorumluluk ve idari sorumluluk olmak üzere ikiye ayrılmaktadır. İdari sorumluluk; idare tarafından kişiye verilen zararın idare tarafından maddi olarak tazmini anlamına gelmektedir. İdare tarafından bu zararın rıza ile tazmin edilmemesi durumunda idari yargı kararı ile zararın tazmini söz konusu olmaktadır ki bu durum da "idari sorumluluk" olarak tanımlanmaktadır (Gözler, 2009: 1007-1011; 1015).

İdarenin sorumluluğu, etkinliklerinin tabi olduğu hukuki rejime dayalı olarak belirlenmektedir (Günday,1997: 243). Dolayısıyla kamu yönetiminde sorumluluk gerek özel hukuk gerekse kamu hukukundan kaynaklanabilmektedir (Gözübüyük, 1994: 269). İdarenin özel hukuka tabi etkinlikleri nedeniyle doğan sorumluluğu hakkında özel hukuk hükümleri uygulanmakta, bu kapsamda ortaya çıkan uyuşmazlıklar da adli yargıda çözüme kavuşmaktadır (Canatan, 2009: 147). İdari sorumluluk ise idarenin kamu hukuku alanındaki etkinlikleri nedeniyle ortaya çıkan zararın karşılamasına ilişkin sorumluluğu olup idarenin bu kapsamda tazmin yükümlülüğü idare hukuku ilkeleri çerçevesinde belirlenmektedir (Gözübüyük, 1994: 272; Canatan, 2009: 147-151; Atay, 2006: 137-165). Zarara uğrayanların idari sorumluluğa dayalı olarak açacakları tazminat davaları da idari yargıda çözümlenmektedir. Buna göre "idarenin

\footnotetext{
${ }^{2}$ Afet; toplumun tamamı veya belirli bir kesimi bakımından fiziksel, ekonomik ve sosyal kayıpların ortaya çıkmasına neden olan, yaşamın olağan akışını ve insan etkinliklerini aksatan veya durduran, etkilediği alandaki insanların kendi kapasiteleri ile üstesinden gelemediği, kaynağı doğa, teknoloji ve insan olan olay olarak tanımlanmaktadır. Afet esas olarak olayın kendisini değil ortaya çıkardığı sonucu anlatan bir kavramdır (AFAD, 2014: 23).
} 
sorumluluğu" esas olarak "idari sorumluluk" tan daha geniş bir anlam taşımaktadır. Ancak "idarenin idari sorumluluğu" anlamına gelen "idari sorumluluk" (Gözler, 2009: 1022; 1033) yerine sıklıkla "idarenin sorumluluğu" ifadesinin kullanıldığı görülmektedir. ${ }^{3}$ Türkiye idaresinin sorumluluğu kuramı esas olarak yasama, yürütme ve yargılama etkinlikleri ile bunları yerine getiren organ ve ajanların bir başka anlatımla kamu gücü ve personelinin mali sorumluluklarını kapsamaktadır. Ancak, devletin yasama ve yargı işlevleri ile ilgili sorumluluğunun, taşıdığı özellikler nedeniyle idarenin genel sorumluluğu rejimi dışında ayrıca incelenmesi, yine personelin kişisel sorumluluğunun da idareninkinden ayrı değerlendirilmesi gerekmektedir (Duran (1974: 3-4). Bu çerçevede çalışmada "idari sorumluluk" ve "idarenin sorumluluğu" kavramları arasındaki farklı kullanımlara ilişkin tartışmadan kaçınımış, gerek idari sorumluluk gerekse idarenin sorumluluğu "idarenin idare hukuku rejimine tabi, kamu hukuku sorumluluğu" anlamında kullanılmış ve inceleme kapsamına idarenin sadece idari işlevden kaynaklanan sorumlulukları dahil edilmiştir.

İdari sorumluluğa gerek kusura dayanan gerekse kusura dayanmayan nedenlerle başvurulabilmektedir (Günday, 1997: 244). Kusurlu sorumlulukta idare tarafından kusurlu eylem ve işlemler ile neden olunan zararın tazmini söz konusudur (Gözler, 2009: 1057). İdari sorumluluk nedeni olarak kusur "[i]darenin kuruluşunda, düzenlenmesinde ve işleyişinde ortaya çıkan bir bozukluk, aksaklık veya boşluktur". Buna göre idarenin örgüt ve etkinliklerinin, başından itibaren iyi düşünülüp planlanmaması, teşkil ve tanzim edilmemesi, gereği gibi veya hiç yürütülmemesi nedeniyle idare, objektif olarak yani belli standart ve ölçülere göre yanlış, eksik, yetersiz ve kötü kabul edildiğinde, kusurludur (Duran, 1974: 26). Bazı durumlarda ise idare herhangi bir kusuru olmasa dahi kişilerin karşılaştığı zararlar nedeniyle sorumlu tutulabilmektedir. İdarenin kusursuz sorumluluğuna başvurulabilmesi için idari davranış ve zarar arasında illiyet bağının kurulması yeterli kabul edilmiştir (Canatan, 2009:149). İdarenin kusursuz sorumluluğu doktrinde sıklıkla risk ilkesi ${ }^{4}$ ile fedakârlığın denkleştirilmesi (kamu külfetleri karşısında eşitlik) ilkesi ayrımı altında incelenmektedir. ${ }^{56}$ Çalışma kapsamında idarenin KBRN tehdit ve tehlikelere bağlı zararlardan doğan kusursuz sorumluluğu risk ilkesi çerçevesinde ele alınmaktadır.

\section{Risk İlkesi}

Doktrinde risk veya hasar kuramı olarak da adlandırılan ilke ile bazı etkinliklerin taşıdığı tehlikelere bağlı olarak kişilere verdiği zararların etkinlik sahiplerinin kusurlu olup olmadıklarına bakılmaksızın tazmini öngörülmektedir. İlkenin uygulanmasında etkinlik ile zarar arasında illiyet bağı bulunması yeterlidir. Bu nedenle idare kusursuz olduğunu kanıtlasa dahi sorumluluktan kurtulamamaktadır (Atay, 2010:131). Dolayısıyla idarenin riske dayalı kusursuz sorumluluğu bakımından belirleyici ölçüt; idarenin etkinliğinin zarar doğurma riski taşıması veya doğası bakımından tehlikeli olmasıdır (Yaşar, 2008: 216).

Gözler (2009: 1168; 1221) risk sorumluluğunu; tehlikeli şeyler, tehlikeli yöntemler, tehlikeli durumlar, mesleki riskler (kamu personelinin görevleri sırasında uğradığı zararlar), idarenin arızi işbirlikçilerinin uğradığı zararlar, bayındırlık eser ve işleri nedeniyle üçüncü kişilerin uğradığı zararlar, toplantı ve gösteri yürüyüşlerinden dolayı ortaya çıkan zararlar ve terör olaylarından dolayı ortaya çıkan zararlar şeklinde bir ayrıma tutmuş, terör olaylarından dolayı ortaya çıkan zararların idarenin kusursuz sorumluluğu dahilinde değerlendirilmeyeceğini savunmuştur. Buna karşın Yaşar (2008: 216-218) idarenin riske bağlı kusursuz sorumluluğu altında temel olarak bayındırlık işleri ve tehlike ölçütünü incelemiş ve tehlike ölçütü altında sosyal risk ilkesini de ele almıştır. Günday (1997:253-255)

\footnotetext{
${ }^{3}$ Kavramın bu yönde kullanımı için bkz: Atay, 2010: 39-41; Günday, 1997: 243-258; Canatan, 2009: 147-151.

${ }^{4}$ Türk hukukunda risk ilkesi öğretide "tehlike ilkesi" olarak da ifade edilmektedir.

${ }^{5}$ Öğretideki çeşitli yaklaşımlar için Bkz.: Özgüldür, 1996: 758-761; Köksal, 2009: 244; Çağlayan, 2009: 453.

${ }^{6}$ Bu yöndeki görüşler için Bkz.: Gözübüyük,1994: 279-282; Gözler, 2009: 1168; Canatan, 2009:149; Günday, 1997: 252-256.
} 
ise idare hukukunda ilkenin uygulama alanını temel olarak; idarenin tehlikeli etkinlikleri ve araç gereçleri, mesleki risk ve sosyal risk şeklinde belirlemiştir.

Çalışmada da idarenin risk ilkesine dayalı kusursuz sorumluluğu; idarenin tehlikeli etkinlikleri ve araç gereçleri, mesleki risk ve sosyal risk ayrımı çerçevesinde incelenmektedir.

\section{1. İdarenin Tehlikeli Etkinlikleri ve Araç-Gereçleri}

İdarenin yerine getirmek zorunda olduğu ve yürüttüğü bazı hizmetler, sahip olduğu araçgereçler ya da kuruluşları doğasında risk unsurunu barındırabilmektedir (Atay, 2010: 169). Dolayısıyla idare tarafından kullanılan araç ve gereçler ile yürütülen etkinliklerin riskli veya tehlikeli olabilmesine bağlı olarak idarenin sorumluluğu ortaya çıkabilmektedir. Bu gibi etkinlikler ve araç gereçler nedeniyle kişilerin uğradığı zarar risk ilkesine dayalı olarak tazmin edilmektedir.

\subsection{Mesleki Risk}

Mesleki risk esas itibariyle risk ilkesinin meslek kazaları bakımından uygulanma biçimidir. İlkeye göre kamu hizmetinde çalışanların görevlerini yürüttükleri sırada veya görevleri ile ilişkili olarak zarara uğraması halinde zarar mesleğin kaçınılmaz tehlikesi olarak kabul edilmekte ve oluşan zarar idare tarafından herhangi bir kusuru olmasa dahi tazmin edilmektedir (Günday, 1997: 253-254).

Kamu hizmetlerinin yürütülmesine gerek kamu makamlarının isteği üzerine gerekse kamu makamlarının herhangi bir talebi olmaksızın kamu personelinin yanı sıra bazı kişiler -ücret karşılığında veya ücret almaksızın çıkan bir yangının söndürülmesine yardım etmek, kaçan suçluyu yakalamak örneklerinde olduğu üzere- kısa süreliğine katılabilmektedir. Bu kişilerin zarara uğraması halinde idare kusurlu olmadığı için, zararın idarenin kusurlu sorumluluğuna dayalı olarak giderimi mümkün değildir. Fransa'da Danıştay kamu yararı amacı ile bir kamu hizmetinin yürütülmesine yardım eden bu kişilerin zararlarının, idarenin bir kusuru olmasa dahi, bu kişilerin yaptıkları yardımdan kaynaklı risk temelinde idarece karşılanması gerektiği yönünde karar vermiştir (Gözler, 2009: 1202-1203). Türkiye'de ise Danıştay, görevleri olmadığı halde kamu hizmetlerine katılanların uğradıkları zararlarda idareyi hizmet kusuruna dayalı olarak tazmin ile yükümlü kılmaktadır. Danıştay'ın bu yaklaşımı zararın kusursuz sorumluluk esasına göre tazmin edilmesi gerektiğine işaret edilerek eleştirilmektedir (Gözler, 2008: 1208-1210; Gözübüyük ve Tan, 2008: 785).

\subsection{Sosyal Risk IIkesi}

Sosyal risk ilkesi idarenin kusursuz sorumluluk halleri arasında doktrin ve yargı içtihatları ile konumlanmıştır (Akça, 2015: 994). İlkenin ortaya çıkmasında; sosyal ve ekonomik koşullara bağlı olarak gelişen kitle hareketleri ve saldırılar ile oluşan zararlara kusursuz kişilerin katlanmasının hak ve adaletle bağdaşmayacağı, bu zararların toplum adına toplumun siyasi örgütlenmesi olan devlet tarafından ödenmesi gerektiği düşüncesi etkili olmuştur (Çoban, 2003: 336-337).

Azrak (1980: 136-145)'a göre: Sosyal risk sorumluluğunda zarar diğer kusursuz sorumluluk hallerinden farklı olarak kamu görevlilerinin davranışları veya idarenin tehlikeli tesislerinden değil, idareye yabancı kişi ve toplulukların idare tarafından önlenemeyen veya önlenmesi halinde daha büyük zararların ortaya çıkmasına neden olabilecek davranış ve eylemlerinden kaynaklanmaktadır. Buna göre diğer kusursuz sorumluluk hallerinin aksine zarar ve idari 
eylem arasında illiyet bağı bulunmamaktadır. Ancak illiyet bağının bulunmamasının sınırsız bir sorumluluk şeklinde yorumlanmaması gerekmektedir. Çünkü ilkeye göre; oluşan zarardan idarenin sorumlu tutulabilmesi için oluşan zararı önlemek idarenin birincil ödevleri arasında bulunmalı, buna karşın idare kusuru olmaksızın zararı önleyememiş veya daha büyük zararların ortaya çıkmasını engellemek için önlemekten kaçınmış olmalıdır. Bu özelliği nedeniyle sosyal risk sorumluluğu idarenin kamu görevlilerinin neden olduğu zararlardan kaynaklanan sorumluluğundan ziyade zarar verici etkinliklerinden kaynaklanan kusursuz sorumluluk hallerine yakındır. Ancak sosyal risk sorumluluğunda zarar verici eylem veya davranışı gerçekleştiren idare değildir. Sosyal risk ilkesinin uygulama alanı toplumsal dayanışmayı etkileyen, dayanışmayı artıran olaylar ile sınılıdır. İlke ile insanların birlikte yaşamalarının ortaya çıkardığı kaçınılmaz tehlike hali sosyal risk olarak kabul edilmekte ve bu tehlikenin doğurduğu zararların idare tarafından illiyet bağı aranmaksızın tazmini öngörülmektedir.

Çoban (2003: 337)'a göre idarenin bu zararları ödeyerek zararların toplumca paylaşılıasının sağlanmasının ardında ise; zararların toplumsal dayanışmayı etkilediği ve toplumda herkesin bu zararlara maruz kalabileceği düşüncesi yatmaktadır.

İlke ve uygulanması doktrinde tartışmaları beraberinde getirmiştir:

Çoğunluk, ilkenin idarenin kusursuz sorumluluğu altında ele alınması gerektiğini savunmaktadır. Ancak ilkenin uygulandığı hallerde esas olarak hizmet kusurunun bulunduğu yönünde görüşler de mevcuttur. Hatta ilke bakımından kusurun tartışılmaması gerektiği veya ilkenin uygulandığı hallerin idarenin sorumluluğunda bulunmadığı da ileri sürülmektedir (Çoban 2003: 337).

Akyılmaz (2005) ilkenin başta yargı kararlarına değil yasama organı düzenlemelerine dayanak oluşturması gerektiğini belirterek ilkeye dayalı yargı kararı verilmesini eleştirmekte, yargı tarafından doğal afetler ve terör eylemleri ile ilgili zararların tazminine yönelik davalarda hizmet kusurunun varlığının araştırılması gerektiğini savunmaktadır. Bununla birlikte Akyılmaz (2005) sosyal risk ilkesine ilişkin genel düzenlemelere örnek olarak 5233 sayılı Kanun ve bu Kanun'a dayalı olarak yürürlüğe konulan Terör ve Terörle Mücadeleden Doğan Zararların Karşılanması Hakkında Yönetmelik'in yanı sıra 6831 sayılı Orman Kanunu'nun değişik 71'inci maddesine dayalı olarak yürürlüğe konulan Orman Yangınlarını Söndürme Çalışmaları Esnasında Ölenlere ve Sakatlananlara Ödenecek Tazminata İlişkin Yönetmelik"i de göstermektedir. Dolayısıyla ilkenin uygulama alanını terörle mücadele ve toplumsal olaylar nedeniyle oluşan zararlar ile sınırlı tutmamaktadır.

Gözler (2009: 1221-1229) e göre: Sosyal risk ilkesi altında ele alınan terör olayları bakımından; idare ancak kusurlu olması halinde sorumlu tutulabilecek, bir başka anlatımla gerçekleşen bir terör olayında idareye atfedilebilir bir kusur bulunmadığı takdirde idarenin bu zarar nedeniyle sorumluluğu bulunmayacaktır. Buna göre idarenin terör olayları nedeniyle risk ilkesine dayalı olarak sorumluluğuna gidilmesi mümkün değildir. Örneğin tehdit edilen bir kişi idareden koruma talep etmiş ve idare bu kişinin koruma talebini reddetmiş ise, bu kişinin teröristler tarafından öldürülmesi halinde idare kusurludur ve hizmet kusuru nedeniyle sorumludur. Bir başka örnekte; idareye bir binaya bomba koyulacağı ihbarı gelmiş ancak idare bunu önleme için gerekli önlemleri almamış ise kusurludur ve kusuru nedeniyle sorumludur. İdarenin terör olayına müdahale ettiği hallerde ise oluşan zarar idarenin kusuru nedeniyle önlenememiş ise idare hizmetin geç veya kötü işlemesinden dolayı kusura bağlı olarak sorumlu olacaktır (Gözler, 2009: 1221-1229).

Günday (1997: 255) sosyal risk ilkesinin mutlak olarak kusursuz sorumluluk ilkesi olarak nitelendirilmesinin uygun olmadığını, terör olaylarının önlenmesi ve terörsüz bir toplum 
KBRN Tehdit ve Tehlikelerden Kaynaklı Zararlar Nedeniyle İdarenin Risk İlkesine Dayalı Sorumluluğu

Administrative Responsibility Regarding the Loss Stemming From CBRN Threats And Hazards Under Risk Principle

düzeninin sağlanması idarenin başlıca görevleri arasında bulunduğundan bunun gerçekleştirilememesinin hizmetin gereği gibi işlememesi şeklinde hizmet kusuru oluşturacağını belirtmektedir.

Gözübüyük ve Tan (2010: 877) kamu düzeninin bozulması ve anayasal düzenin yıkılmasına yönelen anarşi ve terör olayları veya benzer olaylar nedeniyle toplumun zarar görmesi halinde, bu olayların toplumsal risk kapsamında değerlendirilmesi ve oluşan zararın toplumca karşılanması gerektiği düşüncesindedir.

Yaşar (2008: $217-218)^{7}$ ise: İlkeye dayalı olarak tazminde bulunulabilmesi için; zararın toplumsal bir ayaklanma, kargaşa ve savaş nedeniyle meydana gelmesi, idarenin zarara neden olan olayı önleme görevi bulunmasına karşın olayı kusuru olmaksızın önleyememesi veya daha büyük zarar doğmaması için önlemekten bilerek kaçınması gerektiği yönündeki yaygın görüşe eleştirel yaklaşmaktadır. Buna göre kavramların doktrinde ve yargısal içtihatlarda sonsuza dek aynı anlamda kullanılması hastalığına son verilmeli ve kavramlar ilk anlamı ile bağı koparılmadan ancak kapsamı yenilenerek ve geliştirilerek kullanılabilmelidir. Ayrıca risk kavramının sosyalleşmesi ile sadece düzen, dirlik ve güvenlik ile ilgili olayların değil bulaşıcı hastalıklar, bunların tedavisinde oluşabilecek büyük hatalar, depremler ile ortaya çıkan yapı sorunları, sağlıksız kan nakli, çevre sorunlarının zararlı etkileri de dahil olmak üzere bir çok konu ilke kapsamında ele alınmalıdır (Yaşar, 2008: 217-218).

Toplumsal dayanışmayı etkileyen, dayanışmayı arttıran olaylar sadece terör olayları veya siyasal nitelikli saldırılar ile sınırlı değildir. Dolayısıyla Yaşar (2008: 217-218) tarafından da işaret edildiği üzere sosyal risk ilkesinin doğal, insan kaynaklı veya teknolojik afetler, çevre sorunları ve zararlı etkileri vb. konularda da gerek yasal düzenlemelerde gerekse yargı içtihatlarında gözetilmesine bu eylemlerden zarar görenler ile görmeyenler arasındaki dengenin kurulması bakımından intiyaç bulunduğu değerlendirilmektedir.

\section{4. İdarenin Kusursuz Sorumluluğunun Koşulları}

İdarenin kusursuz sorumluluğunun koşullarını; idari davranış, zarar ve idari davranış ile zarar arasında illiyet bağı çerçevesinde ele almak mümkündür:

Ortaya çıkan bir zarar nedeniyle idarenin sorumlu tutulabilmesi için idari işlem veya eylem biçiminde inmali veya icrai bir idari davranışın varlığı aranmaktadır. İdari eylem idari bir işlemin uygulanmasına yönelik olabileceği gibi eylemin herhangi bir idari işleme dayanmaması da imkan dahilindedir (Günday, 1997: 256). Kusursuz sorumlulukta hukuka aykırılık idarenin zararı tazminine ilişkin bir gereklilik değildir (Gözübüyük ve Tan, 2010: 890891). Sorumluluğun sosyal risk ilkesine dayandığı hallerde zarar kamu görevlilerinin davranışları veya idarenin tehlikeli tesislerinden değil, idareye yabancı kişi ve toplulukların idare tarafından önlenemeyen veya önlenmesi halinde daha büyük zararların ortaya çıkmasına neden olabilecek davranış ve eylemlerinden kaynaklanmaktadır (Azrak, 1980: 136-145).

İdarenin sorumluluğu ayrıca tutum ve davranışları nedeniyle ortaya çıkan bir zararın oluşmasını da gerekli kılmaktadır (Özgüldür, 1996: 787). Tazmin edilecek zarar maddi veya manevi olabilmektedir (Karatepe, 1988: 272). Zarardan idarenin sorumlu tutulabilmesi için aranan bazı koşullar ve zararın taşıması gereken birtakım nitelikler de bulunmaktadır: Sorumluluk hukuku cezalandırmayı değil zararın tazmin edilmesini amaçladığından zarar tehlikesi değil zararın varlığı gereklidir. Zararın varlığı koşulları ise; ortada gerçek bir zarar bulunması, zararın gerçekleşmiş olması ve zararın mutlak ve kesin olarak

\footnotetext{
${ }^{7}$ Yaşar (2008: 217) ilkeyi "sosyal risk ölçütü" başlı̆ı altında incelemekte ve çalışmasında "sosyal hasar kuramı" olarak adlandırmaktadır.
} 
hesaplanabilmesidir. Gelecekte kesin olarak ortaya çıkacak zararların da tazmini mümkündür. Zararın tazmin edilebilmesi için ayrıca hukuken korunan bir menfaate ilişkin olması ve para ile ölçülmesinin mümkün olması da gerekmektedir (Atay, 2010: 181-186). İdare hukukunda zararın sorumluluğa yol açması için özel bir nitelik taşıması gerekmekte, herkesi içine alan kamu külfeti niteliğinde ortaya çıkan genel nitelikteki zararlar nedeniyle idarenin sorumluluğuna gidilmeyeceği doktrin ve içtihatlarda kabul görmektedir (Özgüldür, 1996: 787; Gözübüyük ve Tan, 2008: 797). Ayrıca idarenin düzenleyici bir işlemi genel olmakla birlikte belli kişilere özel ve olağandışı bir zarar vermekte ise yine idarenin sorumluluğunu gerektirmektedir (Gözübüyük ve Tan, 2008: 797).

İdarenin sorumluluğunun doğması için bir diğer koşul zarar ile idari davranış arasında illiyet bağının bir başka anlatımla neden- sonuç ilişkisinin kurulmasıdır. Zarar ve davranış arasındaki ilişki ortaya çıkan zararın doğrudan doğruya idari davranışın sonucu olduğunu ortaya koymalıdır. Zararın doğumu, olayların olağan gelişimine göre beklenmeyen bir sonuç ise, idare zarardan sorumlu tutulamamaktadır. Bununla birlikte zararın birden çok nedene dayanması durumunda bu nedenlerden birinin zararı doğurabilecek nitelik taşıması illiyet bağının kurulması için yeterli kabul edilmektedir (Gözübüyük ve Tan, 2010: 892). İlliyet bağı genel olarak kusursuz sorumluluk bakımından idarenin sorumlu tutulabilmesi koşullarından birisidir. Ancak sorumluluğun sosyal risk ilkesine dayandırıldığı hallerde idare, doğrudan idari bir davranıştan kaynaklanmayan zararlardan sorumlu tutulmaktadır (Akça, 2015: 991).

\subsection{Idarenin Kusursuz Sorumluluğunun Kalkması veya Azalması}

İdarenin zarar nedeniyle sorumluluğunu kaldıran veya azaltan haller genel olarak; mücbir sebep, beklenmeyen hal zararın ortaya çıkmasında zarar görenin davranışı, üçüncü kişinin davranışı ve idarenin davranışı şeklindedir (Gözler, 2009: 1329). Bu haller kusursuz sorumluluk bakımından incelendiğinde görülmektedir ki:

Mücbir sebep; idarenin iradesi dışında meydana gelen, idare tarafından en yüksek derecede dikkat ve özen gösterilmesine karşın gerçekleşmesi engellenemeyen ve kamu hizmetinin yürütülmesini imkânsız kılan yer sarsıntısı, sel, aşırı yağış, toprak kayması, yıldırım düşmesi gibi olaylardır. Mücbir sebep, idari davranış ve zarar arasındaki illiyet bağını kestiğinden idarenin kusursuz sorumluluğuna gidilememektedir (Günday, 1997: 257-258). Bununla birlikte idarenin davranışı mücbir sebebin doğurduğu sonuçta bir artışa neden olmakta ise idarenin sorumluluğuna gidilebilmektedir. Ayrıca günümüzde idarenin sahip olduğu teknik olanaklar göz önünde bulundurularak doğa olaylarından kaynaklanan zararlar bakımından idare kusursuz sorumluluğa dayanılarak tazminata mahkûm edilebilmektedir (Gözübüyük ve Tan, 2008: 802).

Beklenmeyen durum; kişinin iradesi dışında oluşması ve önceden tahmin edilerek önlenmesinin mümkün olmaması bakımından mücbir sebebe benzemekle birlikte, mücbir sebepten farklı olarak; idari eylemin içinde oluşmaktadır. Beklenmeyen durumdan zarara neden olan olay ve idare arasındaki ilişkiyi ortadan kaldırmaması nedeniyle idarenin kusursuz sorumluluğunu etkilememekte, idareden kusursuz sorumluluğa dayalı olarak ortaya çıkan zararın tazmin talebinde bulunulabilmektedir (Gözübüyük ve Tan, 2010: 902).

Zararın ortaya çıkmasına zarar görenin kusurunun neden olması idari davranış ve zarar arasındaki illiyet bağını kestiğinden idarenin kusursuz sorumluluğunu ortadan kaldırmaktadır (Canatan, 2009: 150-151). Zarar görenin kusurunun kusursuz sorumlulukta idarenin sorumluluğunu ortadan kaldırabilmesi için zararın ortaya çıkmasında esaslı rol oynaması, idarenin davranışı ve zarar arasındaki illiyet bağını kesmesi gerekmektedir. Ayrıca zarar görenin davranışının zarar doğuran davranışlardan birisi olması durumunda da idarenin 
KBRN Tehdit ve Tehlikelerden Kaynaklı Zararlar Nedeniyle İdarenin Risk İlkesine Dayalı Sorumluluğu Administrative Responsibility Regarding the Loss Stemming From CBRN Threats And Hazards Under Risk Principle

sorumluluğu zarar görenin kusuru ile orantılı olarak azalmaktadır (Gözübüyük ve Tan, 2010: 809).

Zararın tamamen veya kısmen üçüncü kişilerin kusurundan kaynaklanması kusursuz sorumlulukta üçüncü kişinin davranışını idarenin sorumluluğunu kaldırmamakta ve azaltmamaktadır. Bununla birlikte idarenin tazminata mahkûm edilmesi sonrasında üçüncü kişiye kusuru ölçüsünde rücu hakkı bulunmaktadır (Gözübüyük ve Tan, 2010: 812-813).

\section{KBRN Tehdit ve Tehlikelerden Kaynaklanan Zararlar Nedeniyle İdarenin Risk Illkesine Dayalı Sorumluluğu}

Açıklandığı üzere idarenin tehlikeli etkinlikleri ve araç gereçleri nedeniyle doğan zararlar risk ilkesine dayalı olarak tazmin edilebilmektedir. Danıştay da vermiş olduğu;

"Kamu hizmetlerinin görülmesi sırasında bir görevle ilgili olarak genel külfetler dışında fertlere ve ferdi mülkiyete verilen zararların, eylem ile zararlı sonuçlar arasında nedensellik bağının bulunması koşuluyla objektif sorumluluk esaslarına göre ayrıca idarenin kusuru aranmadan hizmetin sahibi idarece tazmin edilmesi hukukun genel ilkeleri ile hakkaniyet ve nefaset kuralları gereğidir" (Danıştay 10. Daire, E.1982/469., K.1982/2357., T. 24.11.1982/ Gözler, 2009: 1179).

şeklindeki kararında idare tarafından kamu hizmetleri görülürken kişilerin can ve mallarına verilen zararlar bakımından sadece zarar ve fiil arasında nedensellik bağının varlığını yeterli görerek ortaya çıkan zararların risk ilkesine göre tazminini kabul etmiştir.

KBRN maddelerin; idarenin yürütmekte olduğu bazı hizmetlerde kullandığı silahlar gibi araç, gereçler ve silah fabrikaları, petrol ve doğalgaz boru hatları bilimsel laboratuvarlar gibi tesisler ve bunlarla ilişkili etkinlikler ile ilişkili olarak zarar doğurma intimali bulunmaktadır. Örneğin kuruluş amacı kapsamında "(...) her çeşit silah, mühimmat, patlayıcı madde, makina, teçhizat ve malzeme (...)" üretmek de bulunan Makina ve Kimya Endüstrisi Kurumu (MKE) demir-çelik, kimya ve makina imalatı gibi pek çok sektörde faaliyette bulunmaktadır (URL-2). Benzer şekilde Boru Hatları ile Petrol Taşıma A.Ş. (BOTAŞ)'ın faaliyet alanları arasında doğalgaz taşımacılığı ve ticareti, petrol ve doğal gaz işletmeciliği, taşımacılığı, depolama gibi etkinlikler bulunmaktadır (URL-3). Dolayısıyla bu kuruluşların faaliyetleri sırasında veya kamu kurum/kuruluşları ya da üniversitelerin laboratuvarlarındaki araç ve gereçlere bağlı olarak KBRN maddeler nedeniyle doğan zararlardan idare kusuru bulunmasa dahi sorumlu tutulabilecektir.

Yine KBRN maddeler ile ilgili görevlerde çalışanların görevleri sırasında veya görevleri ile ilgili olarak zarara uğramaları halinde bu zararın da idare tarafından mesleki risk kapsamında değerlendirilmesi ve risk ilkesine dayalı olarak tazmini gerekmektedir. Danıştayın bomba imha bürosunda görevli polis memurunun bomba patlaması sonucunda ölümü nedeniyle idare aleyhine açtıkları tazminat davasının temyiz aşamasında verdiği kararda yer alan;

"Bomba imhası riskli hizmetlerdir. Yani idarece bütün önlemler, araç, gereç ve personel sağlansa bile aynı sonuç doğabilecektir. Bu nedenle bomba imhası nedeniyle meydana gelen ölüm olayından dolayı ilgililerin uğradığı zararın idare mahkemesi kararında belirtildiği gibi hizmet kusuru ilkesine göre değil, yukarıda aktarılan kusursuz sorumluluk ilkesine göre tazmini gerekmektedir" (URL-4).

şeklindeki yaklaşımı KBRN maddeler ile ilgili görevlerde bulunanların çalıştıkları sırada oluşan KBRN afetler nedeniyle uğrayacakları zararların giderilmesine yönelik tazminat talepleri konusunda emsal oluşturmaktadır: Örneğin Türkiye Afet Müdahale Planı (TAMP)'da 
KBRN Hizmet Grubu olarak belirlenen kurumlarda görevli personelin TAMP kapsamındaki görev ve sorumlulukları (URL-5) yerine getirirken oluşacak zararların konu kararda belirtildiği şekilde mesleki riske dayalı olarak idarece tazmini gerekecektir.

KBRN tehdit ve tehlikelere bağlı olarak ortaya çıkan afetlerde idare tarafından yürütülen faaliyetlerde kamu personelinin yanı sıra kamu makamlarının isteği üzerine veya bu yönde hiçbir talepleri olmadığı halde bazı kişilerin yangın söndürme, yaralılara yardım etme vb. amaçlarla yer alması ve bu sırada zarara uğraması muhtemeldir. Nitekim 7269 sayılı Kanun'da da afet bölgesinde çalışanların yaralanmaları ve engelli hale gelmeleri halinde tedavi giderlerinin karşılanacağı, kurtarma işlerinde çalıştırılanların alet, edevat, malzeme ve vasıtalarının zayi olması ve tamir edilemez hale gelmesi durumunda bunlara ilişkin olarak rayiç bedel özerinden ödeme yapılacağı, kendisine görev verilen bu kişilerden memur olmayanların görev sırasında ölümü halinde tazminat ve ikramiye ödenme koşulları düzenlenmektedir (URL-6). Dolayısıyla söz konusu Kanun'da yer alan bu düzenlemeler KBRN afetlerde çalıştıılanların zararları bakımından da uygulama alanı bulmaktadır. Ancak konu Kanun'da afet bölgesinde çalışanların düzenleyen 10'uncu maddede "çalışanlar" ifadesi kullanılmasına karşın 11 'inci maddede alet, edevat, malzeme ve vasıtalarının zayi olması ve tamir edilemez hale gelmesi durumunda ödeme yapılacaklar için "çalıştırılanlar" ve 12'nci maddede tazminat ve ikramiye ödenecekler için "kendisine vazife verilmiş olanlar" ifadesi tercih edilmiştir. Dolayısıyla özellikle 11 ve 12 'nci madde düzenlemeleri kamu makamlarının isteği dışında yardımda bulunanları kapsamamakta, 10'uncu madde ise bu kişilerin sadece tedavileri ile ilgili masraflarını düzenlemektedir (URL-6). Bu durumda gerek talep üzerine gerekse kendi isteği ile çalıştırılanların uğramış olduğu diğer zararların ise idare tarafından karşılanması gereği doğmaktadır. Gözler (2008: 1208-1210) ve Gözübüyük ve Tan (2008: 785) tarafından da savunulduğu üzere bu kişilerin uğramış oldukları zararların idarenin kusursuz sorumluluğu kapsamında giderimi gereklidir. Bununla birlikte Danıştayın yaklaşımı bu hallerde oluşan zararın kusurlu sorumluluk esasına göre tazmin edilmesi yönündedir (Gözler, 2008: 1208-1210; Gözübüyük ve Tan, 2008: 785).

İdarenin KBRN tehdit ve tehlikelerle ilgili sorumluluğunun sosyal risk ilkesi çerçevesinde ortaya çıkması da mümkündür. KBRN maddelere bağlı olarak oluşan zararların; idareye tamamen yabancı kişi ve toplulukların davranış ve eylemlerinden kaynaklanması, ortaya çıkacak zararın önlenmesinde görevli olmasına rağmen idarenin zararları engelleyememesi veya engellemeye giriştiği takdirde daha büyük zarar intimali bulunması nedeniyle engellememesi durumunda idareden sosyal risk ilkesine dayalı olarak tazmin edilebileceği değerlendirilmektedir.

Sosyal risk ilkesi Türkiye'de gerek içtihatta kabul görmüş gerekse mevzuatta düzenlenmiştir. Danıştaya göre bilimsel ve yargısal içtihatlar ile geliştirilen bu ilkenin amacı kaynağı toplumun içinde bulunduğu koşullar olan, idarenin faaliyet alanında meydana gelmekle birlikte, idarece yürütülen kamu hizmetinin doğrudan sonucu olarak ortaya çıkmayan, buna karşın toplumsal nitelikli riskin gerçekleşmesi sonucu meydana gelen ve sadece toplumun bir bireyi olunması nedeniyle uğranılan özel ve olağandışı zararların topluma pay edilerek giderilmesidir. Danıştay bu bakımdan ilkenin uygulanabilmesi için meydana gelen olayın tüm toplumu ilgilendirilmesi ve zararın toplumsal nitelikli bir riskin gerçekleşmesi sonucu ortaya çıkmasının yanı sıra zarar ile idarenin eylemi arasında bir neden-sonuç ilişkisinin de kurulamaması gerektiği görüşündedir. Buna karşın oluşan zarar ve idari eylem arasında nedensellik bağı kurulan durumlarda öncelikle hizmet kusurunun bulunup bulunmadığının araştırıması, hizmet kusurunun bulunmaması halinde zararın kusursuz sorumluluk ilkesine göre tazmin edilip edilemeyeceğinin belirlenmesi gerektiği, sosyal risk ilkesinin uygulanmasına ise imkân bulunmadığı yine Danıştay tarafından karar altına alınmıştır (URL-7). Danıştay kararlarında sosyal risk ilkesine hangi koşullarda başvurulacağına ilişkin olarak çizilen bu çerçeve ilkenin KBRN tehdit ve tehlikelerden kaynaklanan zararlar bakımından da uygulanmasını mümkün 
kılmakta, dolayısıyla bu kararlar KBRN afetlerde aynı koşullarda ortaya çıkabilecek zararlar bakımından da emsal oluşturmaktadır. Nitekim incelenen Danıştay kararına göre ilke Danıştay tarafından 5233 sayılı Kanun'un yürürlüğüne kadar terör olaylarında gerek maddi gerekse manevi zararlar bakımından uygulanmıştır.

Ayrıca 5233 sayılı Terör ve Terörle Mücadeleden Doğan Zararların Karşılanması Hakkında Kanun genel gerekçesinde belirtildiği üzere "idarenin önlemekle yükümlü olduğu halde önleyemediği" bazı zararların, "nedensellik bağı ve kusur koşulu" aranmaksızın karşılanması gereği göz önünde bulundurularak ve yargısal ve bilimsel içtihatlarla kabul gören sosyal risk ilkesi dikkate alınarak hazırlanmıştır (URL-9). KBRN maddeler ile üretilen silahlar kasıtlı biçimde terör amaçlı olarak kullanılabildiğinden (AFAD, 2014: 23), 5233 sayılı Kanun; KBRN maddeler ile gerçekleşen terör eylemleri veya terörle mücadele kapsamında yürütülen faaliyetler nedeniyle zarar oluşması halinde maddi zarara uğrayan kişilerin, bu zararlarının karşılanması bakımından da uygulama alanı bulmaktadır. Kanun 7'nci maddesi ile hayvanlara, ağaçlara, ürünlere ve diğer taşınır ve taşınmazlara verilen her türlü zararın, yaralanma, engelli hâle gelme ve ölüm hâllerinde uğranılan zararlar ile tedavi ve cenaze giderlerinin ve terörle mücadele kapsamında yürütülen faaliyetlere bağlı olarak kişilerin mal varlıklarına ulaşamamalarından kaynaklanan maddî zararların karşılanması öngörülmüştür. Kanun'da zararın tespiti, yapılacak ödemeler, zararın karşılanma şekli gibi hususlara da yer verilmiştir. Kanun'un 13'üncü maddesinde ayrıca Kanun kapsamında yapılan ödemeler nedeniyle genel hükümlere göre sorumlulara rücu edileceği de düzenlenmiştir. Bu çerçevede KBRN maddelerin terör amaçı kullanılması halinde 5233 sayılı Kanun hükümlerine göre tazmin koşulları oluşmuş ise idare zarardan Kanun ile belirlenen kapsamda sorumlu tutulmaktadır. Kanun'da 12'nci maddede ise uyuşmazlığın Kanun kapsamında sulh yolu ile çözülememesi halinde yargıya başvuru yapılabileceği de belirtilmiştir (URL-10).

Yürürlüğü sonrasında Danıştay Kanun'a dayalı olarak verdiği kararlarda 5233 sayılı Terör ve Terörle Mücadeleden Doğan Zararların Karşılanması Hakkında Kanunun sosyal risk ilkesinin yasalaşmış hali olduğunun altını çizmiştir. Danıştay kararlarında Kanun'un yürürlüğe girdiği tarihten sonraki süreçte terör eylemleri veya terörle mücadele sırasında uğranılan zararların tazmini talebi ile açılan veya açılacak davalarda, artık sosyal risk ilkesinin uygulanma olanağı bulunmadığını, 5233 sayılı Yasanın yürürlüğe girdiği tarihten sonra meydana gelen terör eylemi sonucu oluşan zararın tazmini isteminden kaynaklanan uyuşmazlığın 5233 sayılı Kanun kapsamında çözümlenmesi gerektiğini de belirtmiştir. Danıştayın bu yaklaşımına göre 5233 sayılı Kanun kapsamında karşılanması öngörülen zararlar bakımından ortaya çıkan uyuşmazlıklarda sosyal risk ilkesinin değil, Kanun hükümlerinin gözetilmesi gerekmektedir. Danıştay ayrıca 5233 sayılı Kanun'a göre, terör olayları nedeniyle ancak kişilerin uğradığı maddi zararların karşılanabileceğine, manevi zararların karşılanmasına ise olanak bulunmadığına hükmetmiştir (URL-11).

Oysa Kanun tasarısının genel gerekçesinde tasarının;

"Terör eylemleri veya terörle mücadele kapsamında yürütülen faaliyetler nedeniyle zarar gören kişilerin maddi zararlarının yargı yoluna gitmelerine gerek kalmadan, idarece en kısa süre içinde ve sulh yoluyla karşılanması, Avrupa İnsan Hakları Mahkemesine ancak bu yolla sonuç alamayanların başvurmaları, verilen tazminat miktarlarının haksız zenginleşme aracı olarak kullanılmasının önlenmesi amacıyla (...)" (URL-9)

hazırlandığı belirtilmektedir. Kanun'un 12'nci maddesinde ise;

"Davet yazısında hak sahibinin sulhname tasarısını imzalamak üzere otuz gün içinde gelmesi veya yetkili bir temsilcisini göndermesi gerektiği, aksi takdirde sulhname tasarısını kabul 
etmemiş sayılacağı ve yargı yoluna başvurarak zararının tazmin edilmesini talep etme hakkının saklı olduğu belirtilir.

\section{$(\ldots)$}

Sulhname tasarısının kabul edilmemesi veya ikinci fıkraya göre kabul edilmemiş sayılması hâllerinde bir uyuşmazlık tutanağı düzenlenerek bir örneği ilgiliye gönderilir.

Sulh yoluyla çözülemeyen uyuşmazlıklarda ilgililerin yargı yoluna başvurma hakları saklıdır." (URL-10)

denilmek suretiyle uyuşmazlığın sulh yolu ile çözülememesi durumunda yargı yolunun açık olduğu ifade edilmektedir. Dolayısıyla yargı sürecinde sosyal risk ilkesinin uygulanması mümkündür. Bu nedenle Kanun kapsamında düzenlenmeyen manevi tazminat talebi ile açılan davalarda da sosyal risk ilkesinin gözetilmesi gerekmektedir.

Nitekim Kanun ile ilgili olarak Avrupa İnsan Hakları Mahkemesi 2006 tarihli Aydın İçyer kararında; Kanun'da yalnız maddi zararlar için tazminat talep etme olanağının bulunduğu belirtmiş ancak Kanun'un 12'nci maddesi ile idari mahkemelerde manevi zarar için tazminat talep etme olanağı tanındığının da altını çizmiştir (URL-12). ${ }^{8}$

Aynı konuda Elazığ İdare Mahkemesi tarafından "5233 sayılı Yasa gereğince Zarar Tespit Komisyonu tarafından terör saldırısı sonucu ölenin yakınlarına yapılan sulhname teklifinin kabul edilmemesi nedeniyle açılan maddi ve manevi tazminat davasında, itiraz konusu kuralların Anayasa'ya aykırı olduğu kanısı (...)" ile Anayasa Mahkemesine yapılan başvuruda Mahkeme de (URL-13) sosyal risk ilkesinin uygulanması ile ilgili olarak;

"5233 sayılı Yasa, idarenin eylem ve işleminin sonucu olmayan ve herhangi bir idari işlem veya eylemle doğrudan nedensellik bağı da bulunmayan, ancak terör ve terörle mücadele sırasında meydana gelen zararların da tazmini yolunu açan, bu anlamda idarenin kusursuz sorumluluk alanını genişleten bir yasadır. Bu Yasa idarenin kusursuz sorumluluk alanını genişletmekle birlikte, aynı zamanda terör ve terörle mücadele sırasında meydana gelen zararlardan sadece "maddi" olan kısmının sulh yoluyla tazminine ilişkin esas ve usulleri belirlemektedir. Yasa'da bu zararlardan "manevi" olan kısmın idareden talep edilemeyeceğine ilişkin bir hükme yer verilmediği gibi, 12. maddede "sulh yoluyla çözülemeyen uyuşmazlıklarda ilgililerin yargı yoluna başvurma hakları saklıdır" denilerek Anayasa'nın 125. maddesinin birinci fıkrasına paralel bir düzenlemeye yer verilmiştir. Bu nedenle itiraz konusu ibare, idarenin sorumluluk alanını daraltan veya idari işlem veya eylemlere karşı yargı yolunu kapatan bir hüküm içermemektedir" (URL-13).

şeklinde hüküm tesis etmiştir. Anayasa Mahkemesi konu kararında maddi tazminat miktarı ile ilgili olarak ise;

5233 sayılı Yasa'nın 9. maddesi, terör ve terörle mücadele sırasında meydana gelen yaralanma, sakatlanma ve ölüm hâllerinde ödenecek maddi tazminat miktarı ile ödeme usulünün belirlenmesini düzenleyen bir kuraldır.

\footnotetext{
8 "AiHM, 12.01.2006 tarihinde verdiği kararla davacı Aydın İçyer'in başvurusunu, Avrupa İnsan Hakları Sözleşmesi'nin (AiHS) 8 (özel yaşama, aileye ve konut hakkına saygı ilkesi), 13 (etkili başvuru) ve ek 1 nolu protokolün 1. maddesini (özel mülkiyet hakkı) değerlendirmesi sonucunda, Tazminat Kanunu ile devletin "hem teorik olarak ve hem de uygulamada etkili bir iç hukuk mekanizması oluşturmak konusundaki görevini yerine getirdiği" gerekçesiyle oybirliğiyle kabul edilemez (inadmissible) bulmuştur. Ayrıca bu karardan sonra AïHM, yaklaşık 1.500 benzer müracaatı iç hukuk yolları tüketilmediği gerekçesiyle Sözleşme'nin 35. maddesi uyarınca reddetmiştir." (Kaya, 2007: 27).
} 
Bu kuralda, ölüm halinde (7000) gösterge rakamının memur aylık katsayısı ile çarpımı sonucunda bulunan miktarın elli katı tutarında, ölenlerin mirasçılarına nakdi ödeme yapılacağı belirtilmiştir. Nakdî ödemenin tespitine esas tutulacak miktarın ise ödeme yapılmasına ilişkin valinin veya bakanın onayı tarihinde geçerli gösterge ve katsayı rakamları esas alınarak belirleneceği kuralına yer verilmiştir. Gösterge ve katsayı rakamlarının her yıl artış göstermesi nedeniyle, son işlem tarihinde geçerli gösterge ve katsayı rakamlarının esas alınması, tazminat alacaklısının lehine bir uygulama olduğu açıktır.

Toplumsal nitelikli bir riskin gerçekleşmesi sonucu meydana gelen özel ve olağandışı zararların karşılanmasında, devletin ödeme gücü, ekonomik durumu, zarar görenlerin sayısı, zarar doğuran olayların uzun süreli ve yaygın olması gibi nedenleri gözeterek idare, hizmet kusuru ve kusursuz sorumluluk hallerinde meydana gelen gerçek zarardan sorumlu olurken, sosyal risk ilkesinde sulh yoluyla ödenecek tazminat miktarının yasa koyucu tarafından yasayla belirlenmesi Anayasa'da güvence altına alınan sorumluluk hukukunun temel ilkelerine aykırılık oluşturmaz." (URL-13).

yönünde karar vererek maddenin iptaline ilişkin talebi reddetmiştir.

Avrupa İnsan Hakları Mahkemesi ve Anayasa Mahkemesinin bu karaları Danıştay içtihatlarında da dikkate alınmıştır:

2015 tarihli bir kararda Danıştay açıkça her iki mahkeme kararına da atıf yapmış ve oy çokluğu ile "(...) davacıların manevi tazminata ilişkin talebinin, İdare Mahkemesince manevi zararlara ilişkin 5233 sayılı Kanunda hüküm bulunmadığından bahisle reddedilmesinde hukuki isabet bulunma[dığı]" yönünde hüküm vermiştir (URL-14).

2015 tarihli bir başka kararında da;

“(...) terör eylemi sonucunda hayatını kaybetmesi nedeniyle yakınlarının uğradığı manevi zarar karşılığı adı geçenin babası için 40.000,00-TL, annesi "......." için 40.000,00-TL, kardeşi için 10.000,00-TL ve kardeşi için 10.000,00-TL olmak üzere toplam 100.000,00-TL'nın sosyal risk ilkesi uyarınca davalı idare tarafından tazmini gerektiği sonucuna varıldığı gerekçesiyle davanın kısmen kabulü, kısmen reddi yolunda verilen kararın, hukuka uygun olmadığı ileri sürülerek temyizen incelenerek bozulması istenilmektedir.

(...)temyiz istemine konu kararın hukuka ve usule uygun olduğu, kararın bozulmasını gerektirecek yasal bir sebebin bulunmadığı sonucuna varılmıştır." (URL-15).

şeklinde hüküm tesis ederek manevi tazminat talebini yine kabul etmiştir ${ }^{9}{ }_{-}^{10}{ }_{-}{ }^{11}$.

Sonuç olarak Akça (2015: 1004)'nın da belirttiği üzere Kanun kapsamı dışında kalan toplumsal olaylarda sosyal risk ilkesinin uygulanmasına devam edilmesi mümkündür. Bu nedenle terör olayları dışında kalan toplumsal olaylara bağı olarak KBRN tehdit ve tehlikelerin neden olacağı zararlar konusunda verilecek kararlarda da ilke gözetilmelidir.

\footnotetext{
${ }^{9}$ Karara karşı bir üye "5233 sayılı Kanun, terör eylemleri veya terörle mücadele kapsamında yürütülen faaliyetler nedeniyle maddi zarara uğrayan kişilerin bu zararlarının karşılanmasına ilişkin esas ve usulleri belirlemek amacıyla düzenlenmiş olup, manevi zararlar bu Kanun kapsamında olmadığından, davacıların manevi zararlarının tazmini isteminin kabulüne olanak bulunmadığından, Mahkeme kararının, manevi tazminat isteminin kabul edilmesine ilişkin kısmının bozulması gerektiği oyuyla çoğunluk kararına katılmıyorum." şeklinde karşı oy kullanmışı̧ı.

${ }_{10}$ Danıştay'ın aynı yönde bir diğer kararı için bkz.: URL-16.

${ }^{11}$ Ayturan (2014: 680, http://www.taa.gov.tr/) terör olayları nedeniyle, kişilerin duyduğu elem ve acı ile orantılı bir manevi tazminata hükmedilebilmesini teminen 5233 sayılı Kanun'da manevi tazminata ilişkin düzenleme eklenmesinin uygun olacağı görüşündedir.
} 
Yaşar (2008: 217-218) sosyal risk ilkesinin gerek mevzuatta gerekse içtihatta doğal, insan kaynaklı veya teknolojik afetler, çevre sorunları ve zararlı etkileri vb. gibi farklı konularda da gözetilmesi gerektiğini savunmaktadır. Akyılmaz (2005) da ilkenin yargısal içtihatlarda gözetilmesine karşı olmakla birlikte mevzuatta toplumsal olaylar ve terör olaylarından daha geniş bir alanda uygulandığına işaret etmektedir. Danıştay da ilkenin uygulama amacını;

“(...) idarenin faaliyet alanında meydana gelmekle birlikte, yürütülen kamu hizmetinin doğrudan sonucu olmayan, toplumsal nitelikli riskin gerçekleşmesi sonucu oluşan, salt toplumun bireyi olunması nedeniyle uğranılan özel ve olağandışı zararların da topluma pay edilerek giderilmesi (...)" (URL-7).

olarak belirlemiş ve uygulama koşullarını "(...) olayın tüm toplumla ilgilendirilmesi ve zararın toplumsal nitelikli bir riskin gerçekleşmesi sonucu meydana gelmesi yanında, olay ve zararın yürütülen kamu hizmetinin doğrudan sonucu olmaması, başka bir deyişle zarar ile idari eylem arasında bir nedensellik bağının da kurulamaması (...)"(URL-7) şeklinde ortaya koymuştur.

Bu çerçevede KBRN tehdit ve tehlikeler nedeniyle oluşan zararlar bakımından; olayın ortaya çıkmasına idareye yabancı kişilerin sebep olduğu, idarenin görev alanındaki bu olayı önleyemediği veya daha büyük zararların çıkmaması için önlemediği hallerde -KBRN tehdit ve tehlikelere bağlı zararların terör ve toplumsal olaylardan kaynaklanıp kaynaklanmadığına bakılmaksızın- ilkenin uygulanması gerektiği düşünülmektedir.

Sosyal risk ilkesi ile ilgili Danıştay kararlarında önemli bir diğer husus ise sigorta konusudur. Danıştay bir terör saldırısı sonucu kasko sigortası ile sigortalı bir işyerinde oluşan zararı sigortalıya ödedikten sonra idareye bu zararın yasal faizi ile birlikte kendisine ödenmesi talebi ile rücü eden sigorta şirketinin idareye açtığı davada sosyal risk ilkesinin uygulandığı hallerde devletin sorumluluğunun "(...) kusur esasına dayanmadığı [ayrıca] bu ilkenin uygulanmasında idarenin yürüttüğü hizmetle, meydana gelen zarar arasında nedensellik bağı da aranma[dığı]" na işaret edilerek (URL-17);

"6762 sayılı Türk Ticaret Kanununun halefiyete ilişkin düzenleme yapan 1301'inci maddesinde " Sigortacı sigorta bedelini ödedikten sonra hukuken sigorta ettiren kimse yerine geçer. Sigorta ettiren kimsenin vaki zarardan dolayı üçüncü şahıslara karşı dava hakkı varsa bu hak, tazmin ettiği bedel nispetinde sigortacıya intikal eder. Sigorta ettiren kimse, 1 inci fıkra gereğince sigortacıya intikal eden haklarını ihlal edecek bir hal ve harekette bulunursa sigortacıya karşı mesul olur. Sigortacı zararı kısmen tazmin etmiş ise sigorta ettiren kimse kalan kısmından dolayı üçüncü şahıslara karşı haiz olduğu müracaat hakkını muhafaza eder." hükmü yer almıştır.

Anılan maddede düzenlenmiş bulunan sigortacının halefiyeti, bir şahsın tüm malvarlığının intikali niteliğinde bulunmayıp, sadece sigortalıya ödenen tazminat alacağı miktarı ile sınırlı olduğundan, bu halefiyet yasal, sınırlı ve cüzi halefiyet niteliğindedir. Halefiyete dayalı rücu davası; sigortacının, sigortalının zararını karşıladıktan sonra, onun haklarına halef olarak zararın failine rücu edilmesinden ibaret olup; yerleşik Yargıtay İçtihatlarıyla da kabul edildiği üzere, bu davaların bir özelliği de, doğrudan zarar veren şahsa karşı açılmasıdır. Bu nedenle rücu davalarının, sigortalı ile ona zarar veren arasındaki yasal hükümlere göre görülüp sonuçlandırılması gerekmektedir.

Sigortacının, ödediği bedel kadar sigortalıdan intikal eden dava hakkını, sadece zarar veren şahsa karşı kullanabilmesi mümkün olup; bu halefiyet biçiminin, aksi kanıtlanabilen bir kusur karinesine dayanması nedeniyle, ortaya çıkan bu zararın, yürütülen hizmet ile meydana gelen zarar arasında nedensellik bağını dahi aramadan "kamu külfetleri karşısında eşitlik" 
anlayışıyla topluma pay edilerek giderilmesini amaçlayan sosyal risk ilkesi uyarınca sigorta şirketince de talep edilmesine olanak tanıdığından söz edilemez" (URL-17).

şeklinde karar verilmiştir. Buna göre sigortacılar karşıladıkları zarar nedeniyle rücu davasını ancak doğrudan zarar verene karşı açabileceklerinden, sosyal risk ilkesinin uygulandığı hallerde ise idarenin herhangi bir kusuru bulunmadığından, sigortacının idareye rücu imkânı bulunmamaktadır. Danıştayın bu kararının KBRN tehdit ve tehlikelere bağlı olarak doğan zararlar bakımından sosyal risk ilkesinin uygulandığı hallerde de emsal oluşturduğu değerlendirilmektedir.

\section{Sonuç ve Değerlendirme}

KBRN maddeler idarenin yürütmekte olduğu birçok hizmette kullanılmakta, idarenin ürettiği ve kullandığı silahlar gibi araç, gereçler, silah fabrikaları, petrol ve doğalgaz boru hatları, bilimsel laboratuvarlar gibi tesisler ve bunlarla ilişkili etkinlikler kapsamında idarenin bizzat kendisinin etkinlikleri ile KBRN tehdit ve tehlikelere bağlı zarar doğurma intimali bulunmaktadır.

İdarenin KBRN maddeler kullanılan tesislerinde ve etkinliklerinde çalışanların görevleri sırasında veya görevleri ile ilgili olarak uğradıkları zararlar da yine idarenin kusursuz sorumluluğunu gerektirmektedir.

İdarenin KBRN tehdit ve tehlikeler nedeniyle oluşan zararlar bakımından kusursuz sorumluluğu sosyal risk ilkesine dayalı olarak da ortaya çıkabilmektedir:

Sosyal risk ilkesi Türkiye'de Danıştay içtihatlarında gözetilmekte, ilkeye mevzuat kapsamında da yer verilmektedir. Danıştay'a göre ilke idarenin etkinlik alanında meydana gelen, ancak idare tarafından yürütülen kamu hizmetinin doğrudan doğruya bir sonucu olmayan, sosyal nitelikli riskin gerçekleşmesine bağı olarak ortaya çıkan, kişilerin toplumun bireyi olmaları nedeniyle uğradıkları özel ve olağandışı zararların idare tarafından karşılanması yolu ile topluma paylaştırılmasını amaçlamaktadır. Buna göre ilkenin uygulandığı hallerde zararın toplumun tamamını ilgilendirmesi gerekmektedir. Illke idari eylem ve oluşan zarar arasında bir bağın da kurulamadığı hallerde uygulanmaktadır. Çizilen bu çerçeve ilkenin KBRN tehdit ve tehlikelerden kaynaklanan zararlar bakımından da uygulanmasını mümkün kılmaktadır. İlke Danıştay tarafından toplumsal olaylar ve terör olayları ile ilgili tazminat taleplerinde gözetilmektedir. Bununla birlikte sosyal risk ilkesine ilişkin Danıştay'ın çizdiği çerçeve ilkenin; toplumsal olaylar ve terör olaylarına bağlı olarak KBRN tehdit ve tehlikelerden kaynaklanan zararların yanı sıra örneğin idareye yabancı birinin neden olduğu bir kazada KBRN maddelerin neden olduğu zararlar gibi hallerde uygulanmasını da mümkün kılmaktadır. Kaldı ki ilke gerek terör nedeniyle ortaya çıkan zararlar gerekse orman yangınları gibi diğer zararların tazminine ilişkin olarak çıkarılan mevzuata temel oluşturmaktadır. İlke doğrultusunda hazırlanan ve yürürlüğe konulan ve maddi tazminata ilişkin düzenlemeler içeren 5233 sayılı Kanun kapsamına ise KBRN maddelerin terör amaçlı kullanımı nedeniyle oluşan zararlar girmektedir. Dolayısıyla idareye tamamen yabancı kişilerin davranış ve eylemlerinin yol açtığı KBRN tehdit ve tehlikelere bağlı olarak ortaya çıkan zararlarda idare kusuru olmasa dahi sorumlu tutulabilecektir. Bununla birlikte sigorta söz konusu olduğunda; sigortacının zarar görenin zararını ödedikten sonra zararın doğumunda kusuru olana rücu hakkı doğduğundan, sosyal risk ilkesi ise idarenin kusuru olmaksızın zarardan sorumluluğunu gerektirdiğinden, sosyal risk ilkesi sigortacıya idareye rücu hakkı vermemektedir. Sosyal risk ilkesi gözetilerek idare tarafından karşılanan zararlar esas olarak topluma pay edilmekte, dolayısıyla zarara toplum katlanmaktadır. KBRN tehdit ve tehlikelere bağlı olarak ortaya çıkan zararlarda sosyal risk ilkesinin uygulanma koşullarının bulunduğu 
hallerde zarar görenler zararlarını sigortadan karşıladıklarında ise sigortacının idareye rücu hakkı bulunmamakta, dolayısıyla zarara toplum katlanmamaktadır.

Görüldüğü üzere idarenin KBRN tehdit ve tehlikelerden kaynaklanan zararlar bakımından kusursuz sorumluluğunun risk esasına dayandırılması mümkündür. Konu zararlar ile ilgili olarak idari etkinlik ve zarar arasında illiyet bağı kurulamayan hallerde ise sosyal risk ilkesi uygulama alanı bulmaktadır. İlkenin dayanak oluşturduğu teröre bağlı maddi zararların tazminine ilişkin 5233 sayılı Kanun kapsamında terör nedeniyle meydana gelen zararlar düzenlenmektedir. Terör nedeniyle KBRN tehdit ve tehlikelere bağlı olarak ortaya çıkan manevi zararlar ile yine KBRN maddeler ile ilişkili olarak ancak terör dışındaki nedenlerle gerçekleşen zararların ise çalışmada yer verilen yargı kararları ile çizilen çerçevede kaldığı müddetçe sosyal risk ilkesine dayalı olarak idari yargıda açılacak davalar yolu ile tazmin edilebileceği değerlendirilmektedir. Sosyal risk ilkesinin uygulandığı durumlar hariç olmak üzere kusursuz sorumluluk hallerinde idari davranış ile ortaya çıkan zarar arasında illiyet bağı aranmaktadır. Sosyal risk ilkesinin uygulandığı hallerde ise idarenin bir kusuru aranmadığı gibi idare tarafından yürütülen hizmet ile zarar arasında bir nedensellik bağı dahi söz konusu değildir. 


\section{KAYNAKLAR}

AFAD (2014) Açıklamalı Afet Yönetimi Terimleri Sözlüğü, Ankara: T.C. Başbakanlık Afet ve Acil Durum Yönetimi Başkanlığı.

Akça, K. (2015) “Toplumsal Olaylar Nedeniyle Oluşan Zararlardan İdarenin Sorumsuzluğu," İnönü Üniversitesi Hukuk Fakültesi Dergisi 2 (Özel Sayı), 987-1020.

Akyılmaz, B. (2005) "Sosyal Risk İlkesi ve Uygulama Alanı," Gazi Üniversitesi Hukuk Fakültesi Dergisi, 9(1-2), http://hukuk.gazi.edu.tr/posts/view/title/cilt-9\%2C-sayi-1-2\%28haziran-aralik-2005\%29-17396 (Erişim Tarihi: 01.04.2016).

Atay, E. E. (2006) İdare Hukuku Cilt II, Ankara: Gazi Kitabevi, Kolay Hukuk Serisi:2.

Atay, E.E. (2010) "Idarenin Hukuki Sorumluluğu ve Uygulaması", içine Atay, E. E. ve Odabaşı, H. (2010) Teori ve Yargı Kararları Işığında İdarenin Sorumluluğu ve Tazminat Davaları, Ankara: Seçkin Yayıncılık, 33-249.

Ayturan, Berkan (2014) "5233 sayılı Kanun Kapsamında Manevi Zararların Tazmin Edilip Edilemeyeceği Sorunu," TAAD, 5(19), 653-682, http://www.taa.gov.tr/yayin/etiket/5233-sayilikanun/ (Erişim Tarihi: 10.04.2016).

Azrak, Ali Ülkü (1980) "İdarenin Toplumsal Muhatara Kuramına Göre Kusursuz Sorumluluğu", Sorumluluk Hukukunda Yeni Gelişmeler III. Sempozyumu, İstanbul: İstanbul Üniversitesi Hukuk Fakültesi Yayınları.

Canatan, Bilal (2009) İdare Hukuku, Ankara: Detay Yayıncılık.

Çağlayan, Ramazan (2009) "Risk İlkesi Gereğince İdarenin Kusursuz Sorumluluğu Bağlamında Sosyal Risk İlkesi," Sorumluk ve Tazminat Hukuku Sempozyumu 28-29 Mayıs 2009, 451-495, http://webftp.gazi.edu.tr/hukuk/sorumluluk/s_22.pdf (Erişim Tarihi: 08.04.2016).

Çoban, Ayşegül. (2003) "Yargı Kararları Işığında Sosyal Risk İlkesi," Selçuk Üniversitesi Hukuk Fakültesi Dergisi, 11 (1-2), 319-337.

Danıştay 10. Daire, E.1982/469., k.1982/2357., T. 24.11.1982 [Gözler, Kemal. (2009) İdare Hukuku Cilt II, Bursa: Ekin Basım, Yayın Dağıtım.].

Duran, Lütfi (1974) Türkiye İdaresinin Sorumluluğu, Ankara: Türkiye ve Orta Doğu Amme İdaresi Enstitüü Yayınları [Aktaran: Özgüldür, Serdar. (1996) "İdarenin Hukuki Sorumluluğu ve Tam Yargı Davaları," İ Han Özay (1996) Günışığında Yönetim, İstanbul: Alfa, 709-801].

Gözler, Kemal (2009) İdare Hukuku Cilt II, Bursa: Ekin Basım, Yayın Dağıtım.

Gözübüyük, A. Şeref. ve Tan, Turgut (2010) İdare Hukuku Cilt 1 Genel Esaslar, Ankara: Turhan Kitabevi.

Gözübüyük, A.Şeref. ve Tan, Turgut. (2008) İdare Hukuku Cilt II İdari Yargılama Hukuku, Ankara: Turhan Kitabevi.

Gözübüyük, Şeref (1994) Yönetim Hukuku, Ankara: Turhan Kitabevi. 
Günday, Metin (1997) İdare Hukuku, Ankara: İmaj Yayıncılık.

Karatepe, Şükrü (1988) İdare Hukuku, İzmir: Anadolu Matbaacılık.

Kaya, Cemil (2007) "Avrupa Konseyi'ndeki Gelişmeler Işığında 5233 Sayılı Terör ve Terörle Mücadeleden Doğan Zararların Karşılanması Hakkında Kanun," Uluslararası Hukuk ve Politika, 3(10), 25-42.

Köksal, Mustafa (2009) "Risk İlkesinin İdareye Yüklediği Külfetler ve Güncel Yargı Kararları," TBB Dergisi, 85, 241-272.

Özgüldür, Serdar. (1996) "idarenin Hukuki Sorumluluğu ve Tam Yargı Davaları,” İ Han Özay (1996) Günışığında Yönetim, İstanbul: Alfa, 709-801.

Yaşar, Hasan Nuri (2008) "İdarenin Sorumluluğu Üzerine Düşünceler," İstanbul Üniversitesi Hukuk Fakültesi Mecmuası, 66(1), 201-220.

URL-1: AFAD, KBRN, https://sivilsavunma.afad.gov.tr/icerikler-1040-yonetmelik.html (Erişim Tarihi: 01.04.2016).

URL-2: MKE, Mevzuat, http://www.mkek.gov.tr/tr/Mevzuat.aspx (Erişim Tarihi: 18.06.2017).

URL-3: BOTAŞ, Faaliyet Alanları, http://www.botas.gov.tr/( Erişim Tarihi: 18.06.2017).

URL-4: Danıştay 10. Daire, E. 1996/3996, K. 1997/2544, T. 23.6.1997, http://www.kazanci.com/kho2/ibb/giris.htm ( Erişim Tarihi: 08.04.2016).

URL-5: Türkiye Afet ve Acil Durum Yüksek Kurulu, Türkiye Afet Müdahale Planı (TAMP) (2014, 3 Ocak) T.C. Resmi 28871 http://www.resmigazete.gov.tr/eskiler/2014/01/20140103-12.htm (Erişim Tarihi: 03.04. 2016).

URL-6: 7269 sayılı Umumi Hayata Müessir Afetler Dolayısıyle Alınacak Tedbirlerle Yapılacak Yardımlara Dair Kanun (1959, 25 Mayıs) T.C. Resmi Gazete, 10213, http://www.mevzuat.gov.tr/MevzuatMetin/1.3.7269.pdf (Erişim Tarihi: 02.04.2016).

URL-7: Danıştay 10. Daire, E. 2001/4795, K. 2003/696, T. 25.2.2003, http://www.kazanci.com/kho2/ibb/giris.htm (Erişim Tarihi: 09.04.2016).

URL-8: Danıştay 10. Daire, E. 1994/1682, K. 1995/4256, T. 9.10.1995, http://www.kazanci.com/kho2/ibb/giris.htm (Erişim Tarihi: 10.04.2016).

URL-9: TBMM (2004) Terör ve Terörle Mücadeleden Doğan Zararların Karşılanması Hakkında Kanun Tasarısı ile İçişleri ve Plan ve Bütçe Komisyonları Raporları (1/793), https://www.tbmm.gov.tr/sirasayi/donem22/yil01/ss650m.htm (Erişim Tarihi: 04.04.2016).

URL-10: 5233 sayılı Terör ve Terörle Mücadeleden Doğan Zararların Karşılanması Hakkında Kanun (2004, 27 Temmuz) T. C. Resmi Gazete, 25535, http://www.mevzuat.gov.tr/MevzuatMetin/1.5.5233.pdf ( Erişim Tarihi: 01.06.2016).

URL-11: Danıştay 10. Daire, E. 2009/7423, K. 2009/9167, T. 26.10.2009, http://www.kazanci.com/kho2/ibb/giris.htm (Erişim Tarihi: 08.04. 2016). 
URL-12: Danıştay 15. Daire, E. 2011/16575, K. 2015/6073, T. 15.10.2015, http://emsal.danistay.uyap.gov.tr/VeriBankasilstemciWeb/GelismisDokumanAraServlet(Erişi m Tarihi: 09.04.2016).

URL-13: Anayasa Mahkemesi Kararı, E. 2006/79, K. 2009/97, T. 25.6.2009 (2009, 13 Kasım) T. C. Resmi Gazete, 27405, http://www.resmigazete.gov.tr/eskiler/2009/11/20091113-21.htm (Erişim Tarihi: 9 Nisan 2016).

URL-14: Danıştay 15. Daire, E. 2011/16575, K.2015/6073, T. 15.10.2015, http://emsal.danistay.uyap.gov.tr/VeriBankasilstemciWeb/GelismisDokumanAraServlet (Erişim Tarihi: 04.04. 2016).

URL-15: Danıştay 15. Daire, E. 2015/8734, K.2015/9227, T. 24.12.2015, http://emsal.danistay.uyap.gov.tr/VeriBankasilstemciWeb/GelismisDokumanAraServlet(Erişi m Tarihi: 04.04. 2016).

URL-16: Danıştay 15. Daire, E. 2015/9499, K.2015/9086, T. 23.12.2015, http://emsal.danistay.uyap.gov.tr/VeriBankasilstemciWeb/GelismisDokumanAraServlet(Erişi m Tarihi: 09.04.2016).

URL-17: Danıştay 10. Daire E. 2006/5024, K. 2008/2685, T. 21.4.2008, http://www.kazanci.com/kho2/ibb/giris.htm (Erişim Tarihi: 08.04.2016). 